\title{
THE EFFECT OF SELF-EDITING ON WRITING SKILL OF TWELFTH GRADE STUDENTS OF SMAN 1 LUBUKLINGGAU
}

\author{
Rismar Riansih \\ SMAN 1 Lubuklinggau \\ Lubuklinggau, Indonesia \\ rrismar@gmail.com
}

\begin{abstract}
Self-editing has been considered an important part of writing process that helps improving writing ability and yet become a better writer. This is because by having self-editing, the students are able to recognize their own errors in their composition. Therefore, this current study was conducted to investigate the effect of self-editing on writing skill of twelfth grade students of SMAN 1 Lubuklinggau. The subject of this study consisted of 34 students of grade XII IPA 3. It was found that after experiencing the writing instruction with self-editing, the students' writing skill improved significantly. The students have been very enthusiastic towards the teaching technique. Their score in writing increased from pre-test to the end of cycle II. The result of pre-test showed that the average was 68. From 34 students in the class, only 7 students got the score above 79 and 27 students got the score bellow 79. In addition, in cycle I, the students who got the score above Minimum Mastery Criteria were 12 or 35, 29\% and those who got below the Minimum Mastery Criteria that were 22 or 69, $71 \%$. The average was 75 . Finally, in cycle II, the students who got score above Minimum Mastery Criteria were 30 or $88.24 \%$ and those who got below Minimum Mastery Criteria were 4 or $11.76 \%$. The average score was 81.32. Hence, it can be concluded that self-editing is indeed effective in improving the writing performance of the students. In addition, they could make further revisions on their own errors. Through self-editing, the students were willing to provide further support to peers and learn from each other in the process of writing.
\end{abstract}

Keywords: Self-editing, Discussion text, Writing

\section{INTRODUCTION}

Editing student writing typically takes a few minutes and a red pen. Teaching writing requires hard work, and even though many teachers assign writing, few actually teach the art of writing. The writing process is time consuming and often messy, so it's no wonder that many teachers become default editors. How can teachers be sure that they're teaching students how to write and not simply editing writing assignments (Barber, https://www.edutopia.org/blog/teaching-writing-or-editing-writing-susan- 
barber). Hence, it is needed to involve students in not only write but also edit their own writing.

Barber also adds that teachers should offer feedback throughout the entire writing process and not just on the final product. If writing is done correctly, the majority of the work happens long before the final copy is submitted. When a teacher only offers feedback on the final paper, the window to teach and shape writing has passed, since the student has moved onto the next assignment.

Hence, Barber also said that teachers should not be concerned about marking every grammatical mistake, but rather teach students to self-edit as they write. Correct conventions are an important component of written communication, but very rarely do an essay marked on its every error. Students must learn to self-edit. They can catch many mistakes simply by taking the time to read their paper aloud. Not only does reading aloud add an auditory element to writing, but the process has the added benefit of slowing the reader down long enough to think about the content as well. Providing a simple checklist of common grade-level errors is another way to give students who are not confident in self-editing the support they need to begin taking ownership of the editing process. In addition, teachers can educate students on how to use digital tools such as Grammarly, SAS Writing Reviser, or word processing features to ensure a grammatically correct paper. It can be said that the a student need to edit their own writing that they can be a better writer.

In addition, writing is not over when students have finished their first draft, but after they have revised and edited it. Setting aside time for editing is essential for all of your writing, including in the classs exams. Self-editing seems impossible when a student thinks of it in general. However, when he or she do and solve the task in pieces and prioritize types of errors, then selfediting becomes more manageable. If the students have difficulties with the use of prepositions, but they do not have much problem with verb tenses, then, focus on prepositions exclusively. One or two errors in verbs in your paper will not be as problematic as multiple errors in preposition usage, then 
Riansih, The Effect of Self-Editing on Writing Skill of Twelfth Grade Students...

use the same procedure with different editing categories, one pass through for each one.

There are some research related to the effect of self editing, such as a research done by Diab (2010). He compared the efficacy of self-editing to peerediting in improving students' revised drafts. The study included an experimental group that practiced peer-editing and a control group which engaged in self-editing. The result indicated that training in both peer-editing and self-editing assisted students to revise their essays. The analysis of data also showed that there was a statistically significant difference in revised drafts in favor of peer-editing group. However, those who engaged in selfediting revised more errors compared to the writers who received peer editing (Abadikah, https://www.researchgate.net/profile/Shirin_Abadikah/ publications 2016).

Considering the result of some studies, it can be said that Self-editing can be applied as a way to make writing polished, professional, and effective. Therefore, it can be said that self-editing function as a system for reviewing our work (writing) with a critical eye. By having Self-editing, a writer (in this case the students) can catch the mistakes in their own writing in which it is, sometimes, difficult to do. As a matter of fact, most of us, especially students make mistakes while writing. They occasionally misspell words, use the wrong tense, or stop to reclaim a thought while writing. In addition, generally catching mistakes in ones writing is difficult phenomenon to beat. Fortunately, someone or student can improve your self-editing skills to cut down on mistakes and improve the quality of what you write.

In this paper, self-editing means the activity in which the students edit their own writing after being read by the teacher and given underlined signs on the errors they have made. In this case, the students have to edit their writing in the class under supervised by the teacher.

Therefore, considering the theory and the result of some research related to the problem of this paper, hence presence study aimed at investigating the effect of self-editing done by the twelfth grade students of SMAN 1 Lubuklinggau in their writing performance in writing discussion text. Twelft grade was chosen because the researcher has already observed the 
class before conducted the research and found that the students on the class were still face difficulties in writing. Besides, the reseacher has been a teacher there.

Considering to the problem proposed above, a classroom action research method is applied in the study. This Class-room Action Research is done in two cycles. Each cycle has some steps, they are (1) Planning, (2) Implementation, (3) Observation, and (4) reflection.

As stated by Latief (2010), a Classroom Action Research for English learning aims at developing a certain instructional strategy to solve practical instructional problems in English classrooms. In addition, according to Latief (2012:143), Classroom Action Research for English learning aims at discovering learning teaching strategies that match learners' style and strategies in learning English. Classroom action research is done in several cycles each of which is repeated in the following cycle if the result is not satisfactory yet with the better revised lesson plan. Each cycle begins with lesson planning, implementing the plan, observing the implementation, and reflecting or evaluating the process and the result of the implementation. The result of the reflection then determines the activities of the action on the next cycle.

\section{DISCUSSION}

Based on the observation in the setting of this research, it was found out that the students face difficulties in writing. For them this skill is not a favorite one and they feel bored when they have to attend writing class. This condition affect their writing score: low score.

This, then, affect the writer's curiosity to overcome this hindrances and a classroom action research is needed. Therefore, this study focus on overcoming the students error in writing which are caused by their boredom and subjective feeling: feel dislike to the skill. Hence, this study is trying to investigate the effect of self-editing toward the students' writing performance of the twelfth grade students of SMAN 1 Lubuklinggau. As stated by Latief's opinion in his book Research Method on Language Learning, An Introduction (2012:153), the problems in a classroom action research reflect two things; the 
Riansih, The Effect of Self-Editing on Writing Skill of Twelfth Grade Students...

classroom problems to be solved and the strategy to be developed to solve the problems.

In addition, the self-editing was chosen as the technique in improving the students' writing skill because the focus is on common errors made by students in their writing. It is hoped that the students' error in writing can be minimized by doing self-editing.

In this study, the content, organization, vocabulary, structure and mechanics in writing are the aspects self-editing in writing. These aspects mostly occur in the students' composition. Therefore, this Classroom Action Research was conducted for two cycles to the twelfth grade students of SMAN 1 Lubuklinggau.

In this study, the researcher gave the pre-test to the setting of this research. In the pre-test, it was found out that the result of students' score was still low. Most of the students were not active in the class, their activeness in learning process was not satisfie. Bsides, their motivation in study were also low. In addition, the pre-test was to the students given in form of written test that they have to write a composition of discussion text.

Based on the result of pre-test, it was known that the average of students' score was 68. From 34 students in the class, there were only 7 students got the score above 79 and 27 students got score below 79 . By this reason, the achievement of students in writing discussion text, was still low and did not reach the Minimum Mastery Criteria. Most of the students wrote insufficiently. Their writing have limited knowledge of subject, little substance and inadequate development of topic. Besides, their composition does not show knowledge of the subject i.e non-subjective. In addition, they wrote nonfluently confused or disconnected idea. Some of the students have no organization and limited range of vocabulary, and made errors in using words choice. In addition, their language usage or structure was poor with major problems in writng simple or complex sentences and they also did frequent error of negation agreement, tense, article, pronouns and so on. Finally, their 
mechanics were fair to poor. They made frequent errors of spelling, punctuation, and capitalization.

Table 1

The Result of Pre-test

\begin{tabular}{cccccc} 
& & & & \multicolumn{2}{c}{ Predicate } \\
\cline { 5 - 6 } No & Range & Frequency & Percentage & Pass & Fail \\
& & & & & \\
\hline 1 & $78-100$ & 7 & $20,59 \%$ & Pass & \\
\hline 2 & $0-78$ & 27 & $79,41 \%$ & & Fail \\
\hline & Total & 34 & $100 \%$ & & \\
\hline
\end{tabular}

Hence, it can be concluded that most of the students made errors in all aspects of writing components: vocabulary, structure, organization, content and mechanics. Considering those facts, the researcher tried to improve the twelfth students' writing performance through self-editing in SMAN 1 Lubuklinggau. The result of the pre-test can be seen in the following chart.

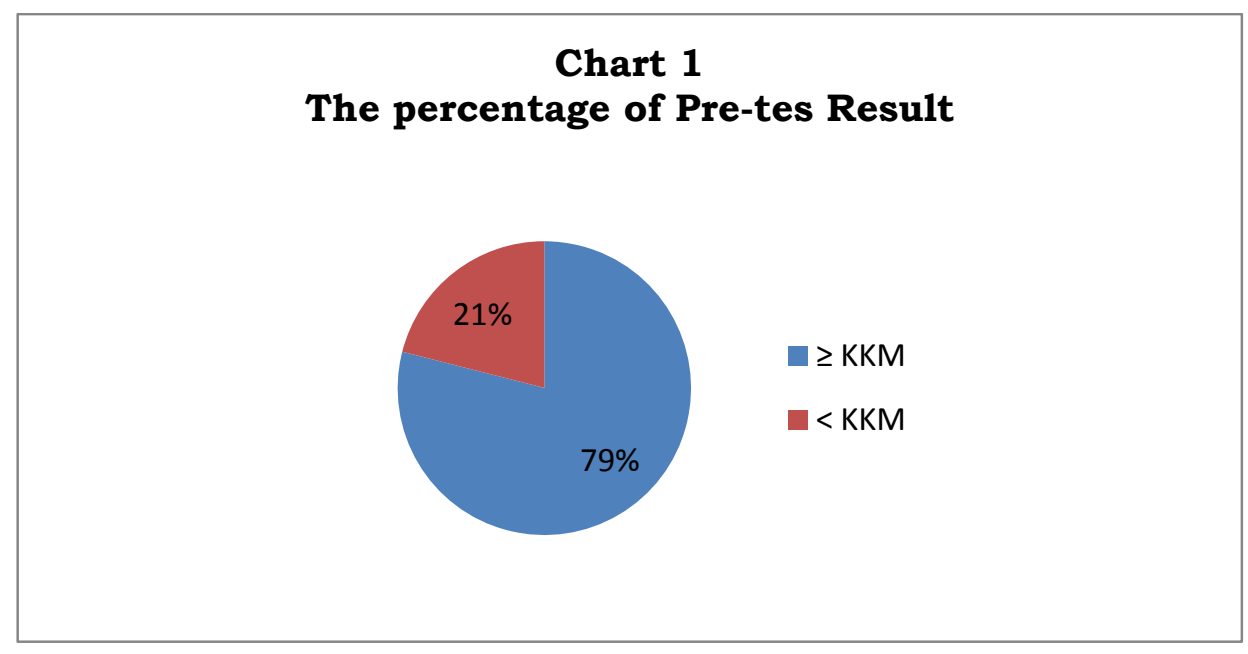

From the chart above, it was known that the students' ability in writing discussion text was still low and there were many students still had not reach the Minimum Mastery Criteria. Quantitatively, the students' average score in pre-test was 68. After having pre-test, then cycle one was done. This cycle was started by designing and making a lesson plan, an observation check lists and instruments tests for each action. In this Class-room Action Research, there 
Riansih, The Effect of Self-Editing on Writing Skill of Twelfth Grade Students...

was an observation in done by other colleges. In the learning and teaching activities, the observers observed the students activities, and the teacher's preparation in doing the research. In addition, the observers also observed the idea which occurred in the process on Classroom Action Research.

Reflection was carried out after observation was done in order to find out the strengths and the weaknesses of the process of this Classroom Action Research and to find out how far self-editing has positive contribution impact on the students' writing performance and whether or not some modification need to be implemented. Finally, it shows that the students' activeness was still low, so the researcher must give motivation to students and they just focus on how to wrute as fast as possible so that they write carelessly and made many error.

In this cycle, the students' score in final test was still very low. This indicated that the students' achievement or the students ability in writing discussion text was still insufficient especially their ability in recognizing and refining their own common errors in writing. In this cycle, students' score in writing discussion text was increased compared the pre-test result) but the increasing still did not achieve the maximum target that is $85 \%$ of students got the score above the Minimum Mastery Criteria. The students whose score above minimum Mastery Criteria were 12 or 35, 29\% and those whose score below the Minimum Mastery Criteria were 22 or $69,71 \%$. The average was 75 .

Table 2

The Result of Cycle I

\begin{tabular}{lccccc}
\hline & & & & \multicolumn{2}{c}{ Predicate } \\
\cline { 4 - 5 } No & Range & Frequency & Percentage & Pass & Fail \\
& & & & & \\
\hline 1 & $78-100$ & 12 & $35,29 \%$ & Pass & \\
\hline 2 & $0-78$ & 22 & $69,71 \%$ & & Fail \\
& & & & & \\
& Total & 34 & $100 \%$ &
\end{tabular}

The results of cycle I test show that the students' score in writing was improve in all aspects of writing criteria. Their writings were average to good category. They have already written with relevant topic, but still lack detail. In 
addition, most of them have already written with standout main ideas and logical sequencing. They also have written with adequate range of vocabulary and occasionaly made errors on word choice. In addition, their structure or language usage was effective but simple. They also made only several errors of agreement, articles, pronouns, preposition. Finally, their mechanics were good. Only some of them made occasional errors of spelling, punctuation. Considering the result of cycle I, it was decided to continue this Classroom Action Research to Cycle II.

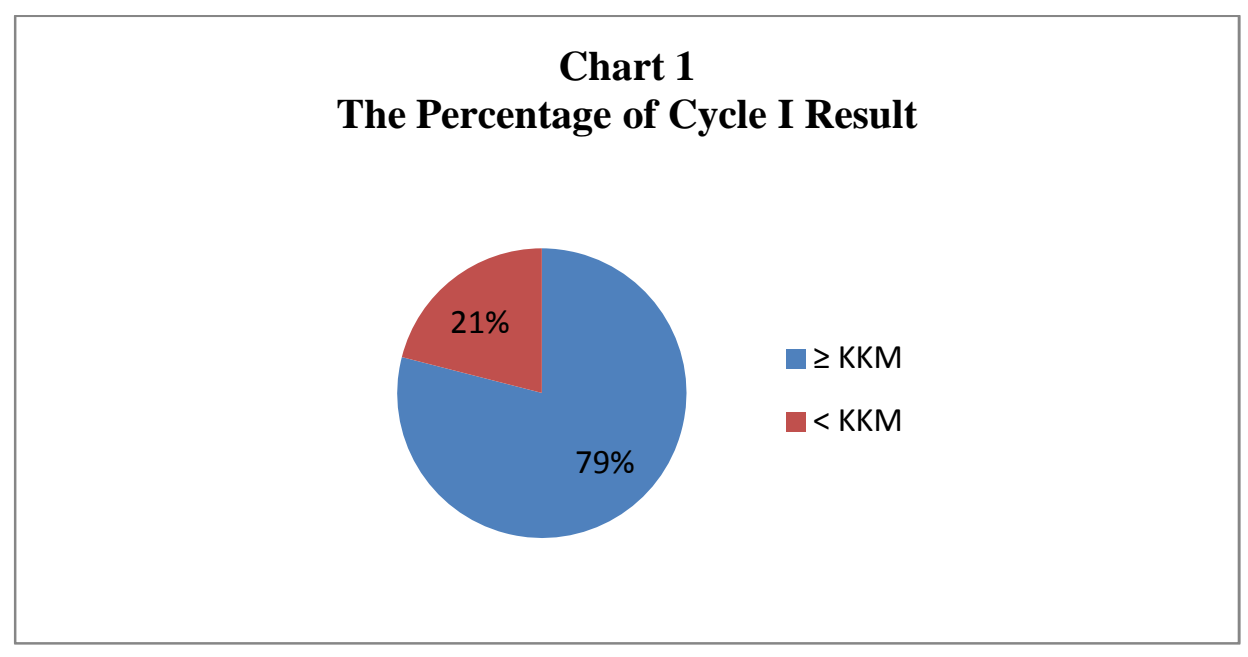

From the data above, quantitatively, the result of the final test in this Cycle I was increased from the average of 68 to 75 . This result indicated that there was an improvement on the students' average that is 10,29 or $(75-68)$ : $68 \times 100 \%$. Therefore, this Classroom Action Research must be continued to the Cycle II although in general, the students' activeness increased from the pre-test.

Considering the result of the reflection in Cycle I, the application in Cycle II was more interesting and was conducted in two meetings. In this cycle, the students did not only wrote discussion text but also tried to recognize and refine their own common error. In Cycle I, the teacher read and gave underlined sign to the error that the students have made in their writing, and then the students have to do self-editing toward it.

In this cycle, there were two meetings. In the first meeting, the teacher explained again the theory of discussion text and reviewing the evaluation 
Riansih, The Effect of Self-Editing on Writing Skill of Twelfth Grade Students...

results on t cycle I and informed the result of self-editing done by the students in test of cycle I, the teacher also explained the common errors made by the students in cycle I.

In the second meeting, the students and the teacher reviewed the evaluation results of cycle I. In this cicle, there was also observation. Here, the observers observed all the process of this Classroom Action Research.

Finally, in cycle II, the students' activeness significantly increased, as a result, the students' score in writing increased significantly.

From the test of cycle II, it shows that the students' score in writing was much better than before. Almost all of the students have already written their composition with good knowledge; able to develop their thesis and were relevant to the topic. There were only few students still have limited development of their idea and thesis. In addition, they have already written in good organizationand were able to express their idea fluently. Moreover, their vocabulary was also very good with appropriate register. Besides, their structure was also very good because they could write effective complex constructions sentences with a few error on tenses numbers, article, pronouns, and preposition although there were still a few students wrote in simple constructions.. Finally, they were able to demonstrate mastery of conventions and occasional made errors of spelling, punctuation.

Table 3

The Result of Cycle II

\begin{tabular}{cccccc}
\hline & & & & \multicolumn{2}{c}{ Predicate } \\
\cline { 5 - 6 } No & Range & Frequency & Percentage & Pass & Fail \\
\hline 1 & $78-100$ & 30 & $88.24 \%$ & Pass & \\
\hline 2 & $0-78$ & 4 & $11.76 \%$ & & Fail \\
\hline & Total & 34 & $100 \%$ & & \\
\hline
\end{tabular}

Statistically, in this cycle, students' score in writing discussion text increased and has achieved the maximum target, which is more than $85 \%$ of students got the score above the Minimum Mastery Criteria. The students got the score above the Minimum Mastery Criteria were 30 or $88.24 \%$ and those whose score below the Minimum Mastery Criteria were 4 or $11.76 \%$. The 
average of the students' score was 81.32 . For the detail, it can be seen on the chart below.

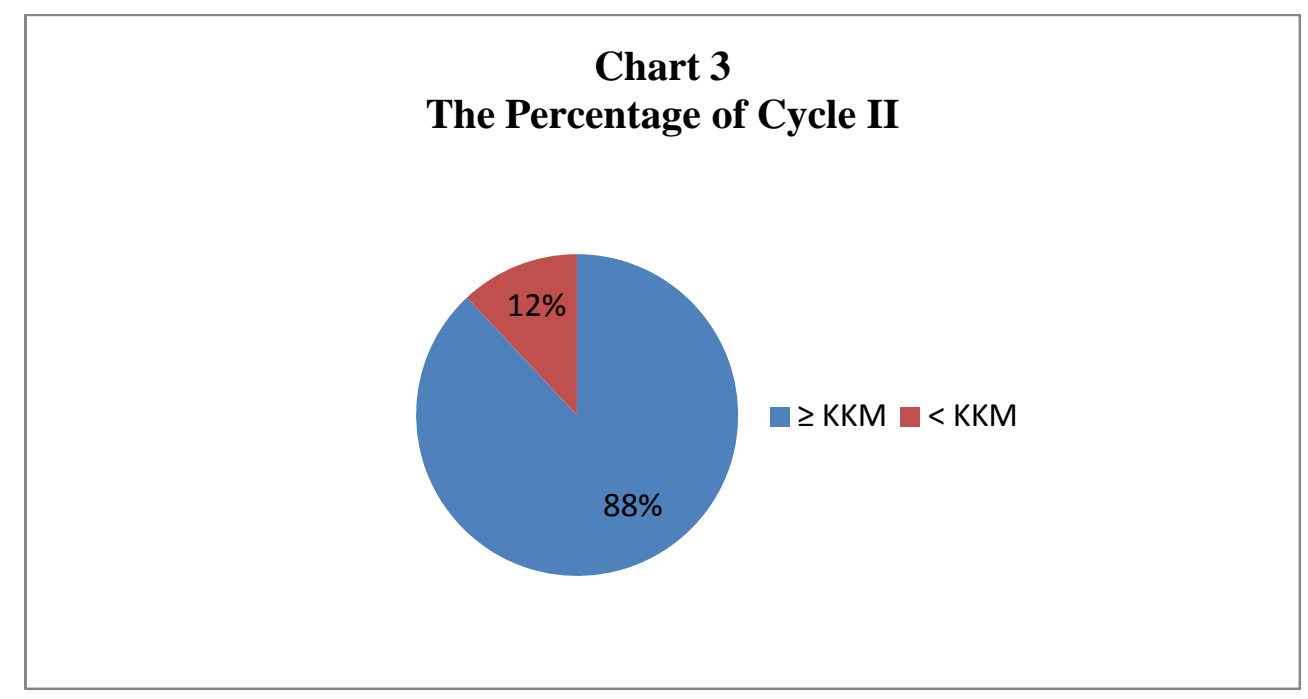

Quantitatively, the average of final test in this Cycle II was increased from the average score of 75 to 80.32 . This result indicated that there was a significant improvement of the students' average that is $7.09 \%$ or $(80.32-75)$ : $75 \times 100 \%$. In addition, it was known that more than $85 \%$ of students got the score above the Minimum Mastery Criteria. The students who got the score above the Minimum Mastery Criteria were 30 or $88,24 \%$ and those whose score below the Minimum Mastery Criteria were 4 or $11,76 \%$. The results of reflectin show that the percentage of students' activeness was significantly high. Moreover, Self-editing has been understood well by students; so that the students are interested in writing. Therefore, this CRA was decided to be stopped because the result has been satisfactory with the better revised lesson plan.

Finally, from the result of Pre-Test, Cycle I and Cycle II, this Classroom Action Research through self-editing has successfully improved the students' writing performance especially in recognizing and refining their writing in discussion text. Therefore, it can be concluded that the self-editing was able to improve the twlwfth grade students' ability in recognizing and refining common error in writing discussion text through self-editing at SMAN 1 Lubuklinggau in the academic year of $2016 / 2017$. 
Riansih, The Effect of Self-Editing on Writing Skill of Twelfth Grade Students...

\section{CONCLUSION}

After having Classroom Action Research, a conclusion is proposed. The conclusion is stated that self-editing has successfully improved the students' skill in writing discussion text. Hence, it can be concluded that the selfediting was able to improve the twlefth grade students' writing skill in recognizing and refining common error in writing discussion text at SMAN 1 Lubuklinggau in academic year of 2016/2017.

In adition, before having CRA especially in pre-test, most of the students wrote insufficiently. After cycle I, the results of final test of cycle I show that the students' skill in writing improved. In addition, after cycle I and II, the students' writing performance increased. The results of final test of cycle II show that the students' writing score was much better than before.

Finally, from the result of Pre-Test, Cycle I and Cycle II, this Class-room Action Research through self-editing has successfully improved the students' ability in writing discussion text at SMAN 1 Lubuklinggau in academic year of $2016 / 2017$.

\section{REFFERENCES}

Abadikhah, Shirin. (2014). Comparison of the effects of peer- versus selfediting on linguistic accuracy of Iranian EFL students. 3L: The southeast asian journal of English language studies - Vol 20(3): 113124113.

Barber, Susan. (2016) https://www.edutopia.org/blog/teaching-writing-orediting-writing-susan-barber. 26/12/2016.

Brown, H. Douglas. (2001). Teaching by principles an interactive approach to language pedagogy. Second Edition. San Francisco: Addison Wesley Longman, Inc.

Corder, S.P. (1982). Error analysis and interlanguage. London: Oxford University Press.

Departemen Pendidikan dan Kebudayaan. (1997). Penelitian tindakan kelas (action research). Jakarta: Direktorat Pendidikan Menengah Umum.

Departemen Pendidikan dan Kebudayaan. (2005). Penelitian tindakan kelas (action research). Jakarta: Direktorat Pendidikan Menengah Umum. 
Diab, N. M. (2010). Effects of peer-versus self-editing on students' revision of language errors in revised drafts. System, 38, 85-95.

Diab, N. M. (2008). The effect of peer-versus self-editing on learner autonomy in ESL writing. Thesis for the degree of Doctor of Education in Linguistics and TESOL. University of Leicester.

Huda, Nuril. (1999). Language learning and teaching issues and trends. Malang: IKIP Malang.

James. (1988). Taxonomy of error analysis. (https://www.yumpu.com/en/ document/view/21961636/1-error-analysis-investigating-the-writingof-esl-/ 15 Browsed on July 03th 2014)

Latief, Adnan. (2012). Method on language learning; an introduction. Malang: UM Press.

Parviz Birjandi \& Masood Siyyari (Allame Tabatabaee Universit). (2015). Selfassessment and peer-assessment: A comparative study of their effect on writing performance and rating accuracy. Iranian journal of applied linguistics, 13(1). 23-45. Browsed on 01/05/2015.

Richards, J.C. (ed.) (1974). Error analysis: perspectives on second language acquisition. London and New York: Longman.

Richards, J.C. and Sampson, G.P. 1974. The study of learner English. In J.C. Richards (ed.) Error Analysis: Perspectives on second language acquisition. London and New York: Longman.

Ur, Penny. 1996. A course in language teaching practice and theory. New York: Cambridge University Press. 